Estudios Geológicos, 66(2)

julio-diciembre 2010, 243-253

ISSN: $0367-0449$

doi:10.3989/egeol.40338.081

\title{
Record of the genus Aeolosaurus (Sauropoda, Titanosauria) in the Late Cretaceous of South America: paleogeographic implications
}

\author{
Registro del género Aeolosaurus (Sauropoda, Titanosauria) \\ en el del Cretácico tardío de América del Sur: \\ implicaciones paleogeográficas
}

\author{
C.R.A. Candeiro ${ }^{1}$
}

\begin{abstract}
The Upper Cretaceous of South America has yielded fossils of the Aeolosaurini titanosaurian Aeolosaurus from Argentina (from the Allen, Los Alamitos, Angostura Colorada, and Bajo Barreal formations) and Brazil (Adamantina and Marília formations). To date, four Aeolosaurus species have been recognized: Aeolosaurus colhuehuapensis, Aeolosaurus rionegrinus, A. rionegrinus? and Aeolosaurus sp. Gondwanatitan faustoi, recently considered a junior synonym of Aeolosaurus, is here demonstrated to be a valid taxon. The occurrence of Aeolosaurus in Turonian-Santonian rocks of central Brazil and in Campanian-Maastrichtian deposits of Argentina suggests that the temporal and geographic distribution of aeolosaurines was greater than previously recognized. The Aeolosaurus records from the Maastrichtian Marília Formation of Brazil demonstrate that this genus persisted after the marine incursion that occurred in northern Patagonia during the Campanian-Maastrichtian. The Late Cretaceous tetrapod assemblages of central Brazil and Patagonia are comparable in age and fossil content.
\end{abstract}

Key words: Aeolosaurus, Titanosauria, Sauropoda, paleobiogeography, distribution, Late Cretaceous, South America, Brazil, Argentina.

\section{RESUMEN}

El Cretácico Superior de América del Sur ha brindado fósiles del titanosaurio Aeolosaurini Aeolosaurus, de Argentina (de las Formaciones Allen, Los Alamitos, Angostura Colorada y Bajo Barreal) y de Brasil (de las Formaciones Adamantina y Marília). Hasta el momento, cuatro especies han sido reconocidas: Aeolosaurus colhuehuapensis, Aeolosaurus rionegrinus, A. rionegrinus? y Aeolosaurus sp. Gondwanatitan faustoi, recientemente considerado un sinónimo junior de Aeolosaurus, aquí se demuestra que es un taxón válido. La presencia de Aeolosaurus en las rocas Turoniano-Santoniano del centro de Brasil y de los depósitos Campaniano-Maastrichtiano de la Argentina, indica que la distribución temporal y geográfica de aeolosaurinos fue mayor que lo reconocido previamente. Los registros de Aeolosaurus en el Maastrichtiano de la Formación Marília, en Brasil, demuestran que este género se mantuvo después de la incursión marina que se produjo en el norte de la Patagonia durante el Campaniano-Maastrichtiano. Las asociaciones de tetrápodos del Cretácico superior del centro de Brasil y de la Patagonia son comparables en edad y contenido de fósiles.

Palabras clave: Aeolosaurus, Titanosauria, Saurópodos, paleobiogeografía, distribución, Cretácico Superior, América del Sur, Brasil, Argentina.

\footnotetext{
1 Laboratório de Geologia, Núcleo de Análises Ambientais em Geociências, Curso de Geografia, Campus do Pontal, Universidade Federal de Uberlândia (UFU), Av. José João Dib, 2545, Bairro: Progresso, Ituiutaba, Minas Gerais, Brazil. Email: candeiro@yahoo.com.br
} 


\section{Introduction}

Aeolosaurus is a well-known aeolosaurine titanosaurian genus from the Late Cretaceous of South America. It has been reported from various Upper Cretaceous localities of this western Gondwanan landmass. In the literature, the paleogeographic distribution of the genus has frequently been reported as the Campanian-Maastrichtian of northern Patagonia (Salgado \& Coria, 1993; Bonaparte, 1996; Powell, 2003). However, recent studies (González Riga, 1999; Bertini et al., 2000; Santucci, 2002; Candeiro \& Martinelli, 2003; Almeida et al., 2004; Candeiro et al., 2004, 2006a,b, 2008; Casal et al., 2007; Santucci \& Arruda-Campos, 2009) have extended the distribution of Aeolosaurus to include other areas of Patagonia (Chubut Province, Argentina) as well as Brazil.

Several anatomical, taxonomic and systematic studies of Aeolosaurus have been published (Wilson \& Sereno, 1998; Salgado \& Garcia, 2002; Wilson, 2002; Powell, 2003; Franco-Rosas et al., 2004; Casal et al., 2007; González Riga et al., 2009). Nevertheless, the paleogeographic distribution of this taxon has not yet been studied in detail. Accordingly, the aim of this paper is to document and analyze the distribution of the genus Aeolosaurus and other aeolosaurine taxa in Argentina and Brazil.

\section{Geological Setting}

\section{Argentina}

\section{Malargüe Group}

The Neuquén Basin (which contains strata belonging to the Malargüe and Neuquén groups) is located in the west-central region of Argentina, and covers Neuquén Province as well as areas of Río Negro, Mendoza, and La Pampa provinces. This basin is important for South American paleontology due to the richness of its Cretaceous dinosaur faunas. It is infilled by intercalated marine, littoral and continental sediments that range in age from the Upper Triassic to the Lower Paleogene (e.g., Digregorio \& Uliana, 1980; Leanza, 1999).

Within the Neuquén Basin, fossils of Aeolosaurus have been collected from the Allen Formation, as well as from equivalent units elsewhere in Patagonia (e.g., the Los Alamitos and Angostura Colorada formations; fig. 1).
The Allen Formation (which crops out in La Pampa and Neuquén provinces) and the Loncoche Formation (in Mendoza Province) were deposited during the late Campanian-early Maastrichtian (fig. 1). They comprise the lower unit of the Malargüe Group and unconformably overlie the Neuquén Group (Legarreta et al., 1989). The beds of the Allen Formation are separated from the Neuquén Group by the lower Campanian Huantraiquican unconformity (Leanza \& Hugo, 2001; Leanza et al., 2004).

The Allen, Loncoche and Los Alamitos formations all consist of fluvial, lacustrine and marginal marine (e.g., tidal flat and lagoonal) facies (Bonaparte et al., 1984; Parras et al., 1996; González Riga \& Parras, 1998; González Riga, 1999; Previtera \& González Riga, 2008). They are related to an "Atlantic" marine ingression from the east that covered central and northern Patagonia toward the end of the Cretaceous Period (Wichmann, 1927; Barrio, 1990; Casadío, 1994).

\section{Chubut Group}

The Chubut Group (which consists of the Matasiete, Castillo, Bajo Barreal, and Laguna Palacios formations) is exposed in south-central Chubut Province, central Patagonia, Argentina. Its principal vertebrate-bearing strata belong to the Bajo Barreal Formation, which is divided into a Lower Member (that dates to the middle Cenomanian-Turonian) and an Upper Member (Campanian-?Maastrichtian; fig. 1) (Sciuttio \& Martínez, 1997; Bridge et al., 2000). This group contains the most important Upper Cretaceous vertebrate remains from Chubut Province (e.g., Martínez, 1998; Martínez et al., 2000; Lamanna et al., 2002; Martínez et al., 2004).

\section{Brazil}

\section{Bauru Group (Adamantina and Marília formations)}

The Bauru Group (fig. 1; sensu Fernandes \& Coimbra, 1996; Dias-Brito et al., 2001) is the most intensely studied unit in the Bauru Basin. In stratigraphic order, the Bauru Group is comprised by the Adamantina (Turonian-Santonian), Uberaba (Turonian-Coniacian) and Marília (late Maastrichtian) formations. The Caiuá Group is another unit in the Bauru Basin. It is composed of the Rio Paraná (Santonian-Maastrichtian), Goio re (Santonian-Maas- 


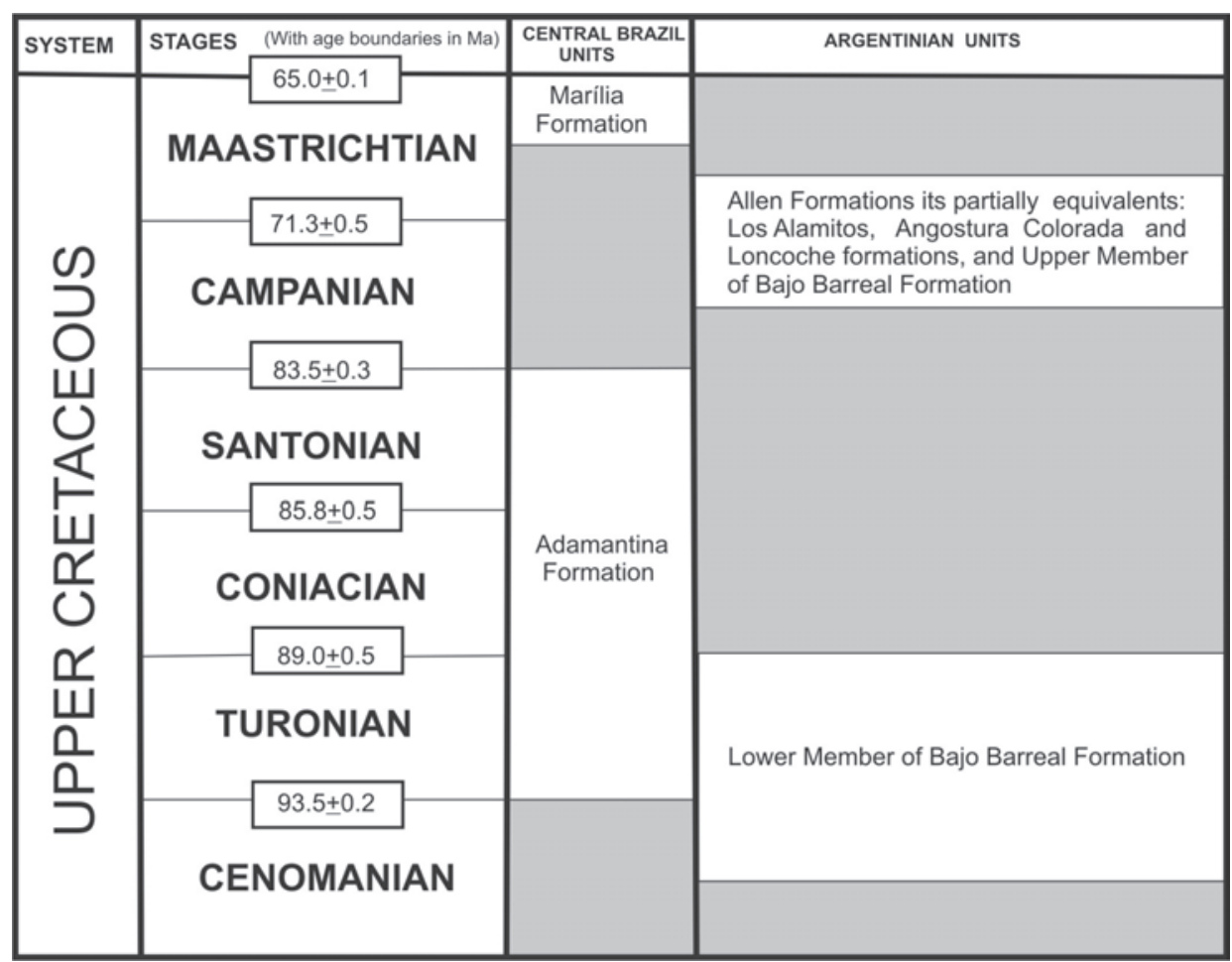

Fig. 1.-Stratigraphic chart of some Late Cretaceous formations of Argentina and Brazil (absolute ages from Remane, 2000).

trichtian), and Santo Anastácio (Aptian-Cenomanian) formations. The Bauru Group has a complex nomenclatural history (Barcelos, 1984; Fernandes \& Coimbra, 1996), partially due to the artificial division of the Upper Cretaceous strata in the flat areas of Goiás, Mato Grosso do Sul, Minas Gerais (Triângulo Mineiro), Paraná and São Paulo states.

Both the Adamantina and Marília formations have been chronologically correlated with Upper Cretaceous strata in Argentina (e.g., the Bajo Barreal, Angostura Colorada, Bajo de la Carpa, Los Alamitos, and Allen formations) (Huene, 1927, 1939; Candeiro et al., 2006; Candeiro, 2007). The strata of the Adamantina and Marília formations were successively described as the Bauru Grez (Gonzaga de Campos, 1905), Bauru Series (Freitas, 1955), Bauru Formation (Washburne, 1930; Arid, 1967; Mezzalira, 1974) and Bauru Group (Soares et al., 1980; Suguio, 1980; Dias-Brito et al., 2001) within the Paraná Basin. Other workers further subdivided these formations (e.g., Fernandes, 1998).

The recognition and description of the stratigraphic relationships among the various formations of the Bauru Basin has allowed a better understanding of its extensive fossil assemblages in a chronostratigraphic context.

\section{Taxonomy}

In order to evaluate the taxonomic status of Aeolosaurus, I use information obtained from Franco-Rosas et al. (2004), Calvo et al. (2007) and González Riga et al. (2009). Data on Aeolosaurus species are derived primarily from the literature as well as from direct observations of specimens. The term Titanosauria is used sensu Wilson and Upchurch (2003), as the clade of Andesaurus delgadoi, Saltasaurus loricatus, their most recent common ancestor and all descendants. The definition of the tribe-level taxon Aeolosaurini employed here follows those proposed by Franco-Rosas et al. (2004), Casal et al. (2007) and González Riga et al. (2009). Aeolosaurini is currently comprised by Aeolosaurus rionegrinus Powell (1987), Aeolosaurus colhuehuapensis Casal et al. (2007) and Gondwanatitan faustoi Kellner \& Azevedo (1999).

Institutional abbreviations: Argentina - IANIGLA-PV, Instituto Argentino de Nivología, Glaciología y Ciencias Ambientales, Colección Paleovertebrados, Mendoza. MPCA, Museo Provincial "Carlos Ameghino", Cipolletti, Río Negro. MJG, Museo "Jorge Gerhold”, Ingeniero Jacobacci, Río Negro. UNPSJB, Universidad Nacional da Patagonia San Juan Bosco, Comodoro Rivadavia, Chubut. Brazil - LGP, Laboratório de 
Geologia e Paleontologia Universidade Federal do Rio Grande, Rio Grande, Rio Grande do Sul. MN, Museu Nacional, Rio de Janeiro. MPMA, Museu de Paleontologia de Monte Alto, São Paulo. UFRJ-DG, Departamento de Geologia, Universidade Federal do Rio de Janeiro.

\section{Paleogeographic distribution of Aeolosaurus}

The following is a brief review of the geographic, stratigraphic and vertebrate faunal contexts of known specimens of Aeolosaurus (fig. 2; table 1).

\section{Argentina}

\section{Chubut Province}

Aeolosaurus colhuehuapensis (holotype: UNPSJB-PV 959) was recently described by Casal et al. (2007) from the Upper Member of the Bajo Barreal Formation as exposed on an ephemeral island in Lago Colhué Huapi in south Chubut Province. According to Casal et al. (2007), the level of the Upper Member from which A. colhuehuapensis was recovered is of Campanian-?Maastrichtian age, in contrast to the Lower Member of the Bajo Barreal Formation which is regarded as Cenomanian-Turonian. These articulated specimens of the $A$. colhuehuapensis consist of procoelous anterior and middle caudal vertebrae and haemal arches. Associated vertebrate fauna: an indeterminate mesoeucrocodylian and a derived iguanodontian ornithopod.

\section{Mendoza}

?Aeolosaurus-related species (IANIGLA-PV 032, 229, 250). González Riga (1995, 1999) published a brief description of fragmentary titanosaurian remains collected from the Loncoche Formation of the Malargüe Group (Campanian-Maastrichtian; Mendoza Province, Argentina). Between 2001 and 2004, additional remains (IANIGLA-PV 231) were discovered (Previtera \& González Riga, 2008). The teeth are similar to those recovered from the Los Alamitos Formation and attributed to Aeolosaurus (Bonaparte et al., 1984) although no dental characters are yet known to be diagnostic of this genus (González Riga, pers. comm.). The fossil vertebrate faunas of the Loncoche and Los Alamitos formations are similar, and occur at the onset of the "Atlantic" marine ingression that began during the
Late Cretaceous. Associated vertebrate fauna: fishes (Rajiformes, Semionotiformes, Lepisosteidae, Teleostei [Perciformes \{Percoidei\}], Dipnoi [Ceratodontidae]), frogs (?Leptodactylidae), turtles (Cheloidea), snakes (Boidae), plesiosaurs, titanosaurs and theropods (González Riga, 1999). Recently, González Riga and Calvo (2009) described the sauropod ichnotaxon Titanopodus mendozensis from the Loncoche Formation. These trackways show a wide-gauge style of locomotion and lack impressions of manual phalanges. Because of this, the authors argued that the trackmakers were probably medium-sized saltasaurine or aeolosaurine titanosaurs.

\section{Río Negro Province}

Aeolosaurus rionegrinus (holotype: MJG-R-1, MACN-RN 147). A. rionegrinus was described by Powell (2003) and occurs in the uppermost Cretaceous (Campanian-Maastrichtian) Allen, Angostura Colorada and Los Alamitos formations of Río Negro Province. The postcranial skeleton of $A$. rionegrinus is one of the most completely known of any titanosaurian. Associated vertebrate fauna: fishes (Rajiformes, Lepisosteidae, Teleostei [Diplomystidae, Ariidae, Percoidei] Reatodontodi), frogs (Pipidae, Leptodactylidae), turtles (Chelidae, Meiolaniidae), snakes (Boidae), ornithopods ("Kritosaurus" australis), abelisauroid theropods (Quilmesaurus curriei, Allen Formation), and mammals (nine "families").

Aeolosaurus rionegrinus? (Powell, 2003). (According to Salgado et al. (1997), material referred to "Aeolosaurus rionegrinus?" is housed in the MPCA, not in the Museo Argentino de Ciencias Naturales "Bernadino Rivadavia".) Aeolosaurus rionegrinus? is known from strata of the Los Alamitos Formation exposed on the Estancia Los Alamitos, Cona Niyeu, Río Negro Province. According to Powell (2003), the morphology of the caudal centra and neural arches, the position and length of the prezygapophyses, and the orientation and relative position of the postzygapophyseal facets are very similar to the conditions observed in Aeolosaurus rionegrinus from Casa de Piedra, Río Negro Province. Associated vertebrate fauna: same as for Aeolosaurus rionegrinus.

Aeolosaurus sp. (MPCA 27174, 27175, 27176, 21177). Aeolosaurus sp. (Salgado \& Coria, 1993) was collected from the Allen Formation (upper Campanian-lower Maastrichtian; Leanza \& Hugo, 
2001) at Salitral Moreno, Río Negro Province, approximately $20 \mathrm{~km}$ southwest of the town of General Roca. Salgado \& Coria (1993) noted that Aeolosaurus sp. differs from Aeolosaurus rionegri$n u s$ in the length of the caudal prezygapophyses, the relative position of the postzygapophyses, its radial and ischial morphology, and in its possession of dermal plates. Associated vertebrate fauna: sauropods (Rocasaurus muniozi and faveoolithid eggs), ornithopods ("Kritosaurus" australis and a purported lambeosaurine), abelisauroid (Quilmesaurus curriei) and maniraptoran theropods and the bird Limenavis patagonica.

\section{Brazil}

\section{Minas Gerais State}

Aeolosaurus sp. (CPP 374). Bertini et al. (2000) assigned to Aeolosaurus sp. two caudal vertebrae recovered from the upper Maastrichtian Serra da Galga Member, Marília Formation, Bauru Group of the Peirópolis site, Uberaba. These vertebrae are characterized by the presence of strongly procoelous centra, a synapomorphy of Titanosauria (sensu Salgado et al., 1997; Wilson, 2002), and caudal heart-shaped transverse section and anteroposterior compression. This allows the assignment of the vertebrae in question to Aeolosaurus (Bertini et al., 2000). Associated vertebrate fauna: frogs (Baurubatrachus pricei), turtles (Podocnemidae), mesoeucrocodylians (Peirosaurus tormini, Uberabasuchus terrificus, Itasuchus jesuinoi), sauropods (titanosaurs and megaloolithid eggshell) and abelisauroid and carcharodontosaurid theropods.

Aeolosaurus-related titanosaur (UFRJ-DG 270-R, caudal vertebra). An Aeolosaurus-like caudal vertebra from the Turonian-Santonian Adamantina Formation, Bauru Group, at the Prata site in Minas Gerais State was described by Almeida et al. (2004). This vertebra is nearly complete and possesses a deep and relatively low, procoelous centrum with a heart-shaped anterior articular facet. The heartshaped posterior articular facet and wide prezygapophyses support the assignment of this vertebra to Gondwanatitan or Aeolosaurus (Almeida et al., 2004; Candeiro et al., 2004). Associated vertebrate fauna: turtles, crocodyliforms, titanosaurs and abelisaurid and carcharodontosaurid theropods.

cf. Aeolosaurus (LGP 0001-0010). Two procoelous vertebral centra, a right coracoid and tibia, a possible phalanx and several unidentified fragments from the Maastrichtian Marília Formation, Bauru Group, at Peirópolis, Minas Gerais State were described by Lopes \& Buchmann (2008). These specimens were referred to Aeolosaurus because one of the caudal vertebrae (LGP 0005) is heart-shaped in cross-section, has an anteroposteriorly compressed ventral half and has pleurocoellike depressions on its anterolateral portion (Lopes \& Buchmann, 2008). Associated vertebrate fauna: same of the CPP 374.

\section{São Paulo Sate}

Aeolosaurus sp. (MPMA 427). Santucci (2002) described a caudal vertebra from the Turonian-Santonian Adamantina Formation of the Bauru Group, from the vicinity of the town of Monte Alto in western São Paulo State, Brazil. This small vertebra is dorsoventrally low, procoelous and bears a heartshaped anterior articular facet. Associated vertebrate fauna: fishes (cf. Neoceratodus, Lepidosteus cominatoi, Osteoglossidae and Siluriformes), frogs (Neobatrachia), turtles (Roxochelys harrisi, Roxochelys wanderleyi, Roxochelys elegans, Bauruemys brasiliensis, cf. Podocnemis and Podocnemididae? indet.), lizards, crocodyliforms (Armadillosuchus arrudai, Baurusuchus pachecoi, Baurusuchus salgadoensis, Mariliasuchus amarali, Mariliasuchus robustus, Morrinhosuchus luziae, Sphagesaurus huenei, Stratiotosuchus maxhechti, ?Goniopholis paulistanus, ?Brasileosaurus pachecoi), titanosaurs (Antarctosaurus brasiliensis [a nomen dubium], Gondwanatitan faustoi), abelisaurid and carcharodontosaurid theropods and a mammal.

Aeolosaurus sp. (MPMA 477). A caudal vertebra from the upper Maastrichtian Echaporã Member of the Marília Formation is the only record of this genus in this member of the Bauru Group. According to Santucci (2002), this vertebra presents the same conditions as Aeolosaurus sp. from the Adamantina Formation. Associated vertebrate fauna: titanosaurs.

Gondwanatitan faustoi (MN 381). Kellner \& Azevedo (1999) described this taxon on the basis of a nearly incomplete skeleton recovered from the Turonian-Santonian Adamantina Formation of Santo Anastácio, São Paulo State. G. faustoi was interpreted as a member of "Titanosauridae" by Kellner \& de Azevedo (1999) and Salgado \& Garcia (2002), and later as a titanosaur closely related 
to Austrosaurus and Lirainosaurus (Upchurch et al., 2004). Bertini et al. (2000) and Santucci (2002) considered this species to be synonymous with Aeolosaurus based on the anterodorsally projected neural spine of the anterior caudal vertebrae as well as some appendicular characters. However, Gondwanatitan and Aeolosaurus can be differentiated on the basis of a number of features, such as: 1) centrum of the sixth sacral vertebra with concave posterior articular surface in Gondwanatitan; 2) heartshaped posterior articular surfaces on anterior and middle caudal vertebrae in Gondwanatitan; 3 ) prominent lateral ridge on the basal portion of the neural arch of the middle caudal vertebrae in Gondwanatitan; 4) large articulation of the prezygapophyses in Aeolosaurus and corresponding articulation absent in Gondwanatitan; 5) lateral tuberosity on ischium of Gondwanatitan; 6) iliac peduncle of ischium less expanded in Gondwanatitan; 7) medial ischial plate less expanded in Aeolosaurus; 8) more slender humerus in Aeolosaurus. On this basis, I refute the proposed synonymy of these two genera and instead consider them distinct.

\section{Discussion}

From existing data on the paleogeographic and stratigraphic distribution of the genus, it is clear that Aeolosaurus ranged from at least southern Patagonia to central Brazil. Aeolosaurus colhuehuapensis, Aeolosaurus rionegrinus, Aeolosaurus rionegrinus?, Aeolosaurus sp., and Aeolosaurus-related taxa have all been discovered in Argentina; Aeolosaurus sp. and Aeolosaurus-related taxa are known to occur in Brazil. The following are recorded in the Turonian-Santonian (of Brazil): Aeolosaurus sp. and Aeolosaurus-related taxa. In the CampanianMaastrichtian (of Argentina) occur Aeolosaurus colhuehuapensis, Aeolosaurus rionegrinus, Aeolosaurus rionegrinus?, Aeolosaurus sp. and Aeolosaurus-related taxa; Aeolosaurus sp. is known from the Maastrichtian (of Brazil) (fig. 2, table 1).

The genus Aeolosaurus has so far been recorded at ten Late Cretaceous localities in Argentina and Brazil. Conversely, Aeolosaurus is not presently known to have occurred in other areas of Gondwana. The paleogeographic distribution of Aeolosaurus therefore appears to be the product of Late Cretaceous faunal interchange within South America. The observed distribution of Aeolosaurus

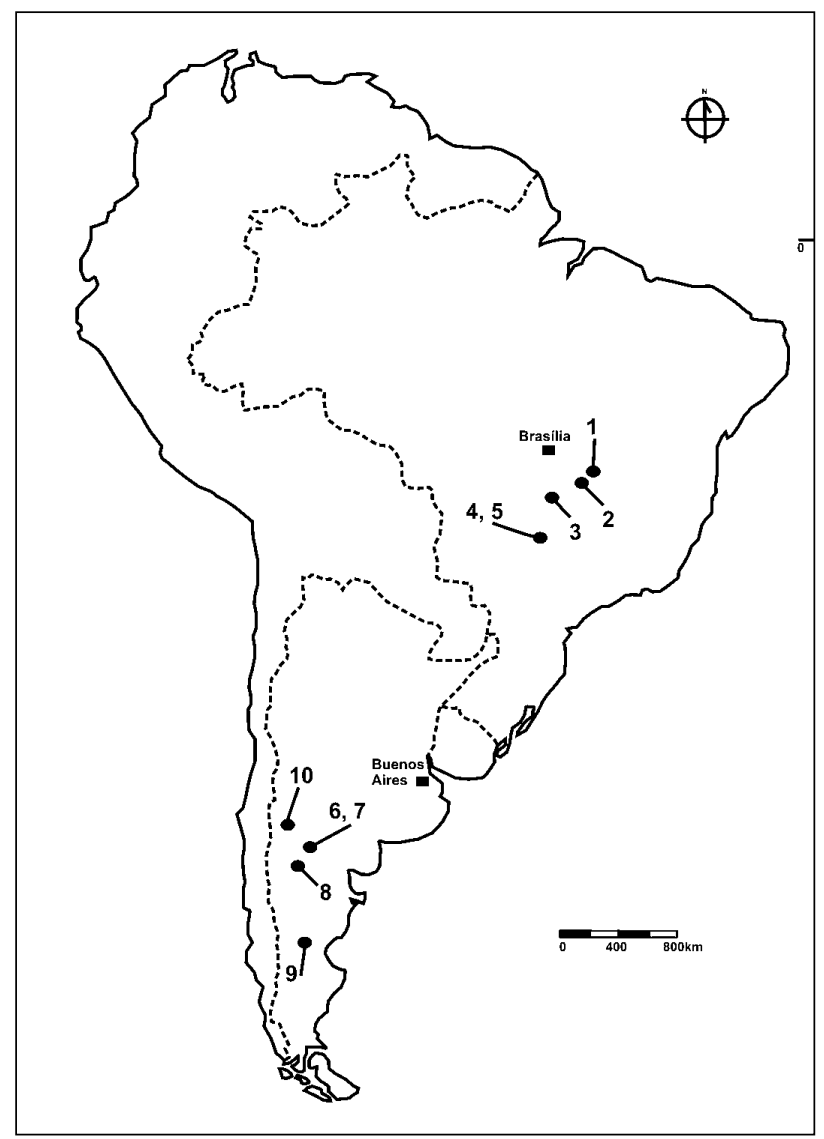

Fig. 2.-Late Cretaceous southern South America Aeolosaurus records. Brazil: 1) Aeolosaurus sp, Peiropolis, Minas Gerais State; 2) cf. Aeolosaurus, Veríssimo, Minas Gerais State; 3) Aeolosaurus-related, Prata, Minas Gerais State; 4) Aeolosaurus sp., Monte Alto, São Paulo State; 5) Aeolosaurus-related. Argentina; 6,7$)$ Aeolosaurus rionegrinus, Estancia Maquichao, Río Negro Province; 8) Aeolosaurus rionegrinus?, Cona Niyeu, Río Negro Province; 9) Aeolosaurus sp., Lago Colhue Huapi, Chubut Province; 10) Aeolosaurus-related teeth, Mendonza Province.

in southern South America may be a product of evolutionary change, dispersal or selective preservation. Possible differences in the composition of aeolosaurine species, both in space and time in southern South America, could have originated from paleoecological trends that might be reflected in features such as lithology. However, in Argentina and Brazil, Aeolosaurus is the most commonly reported sauropod genus and consequently this taxon may have been very abundant compared to other South American titanosaurs. Why Aeolosaurus has not yet been found in other areas of South America is unknown.

The earliest occurrence of Aeolosaurus is from the Turonian-Santonian Adamantina Formation (Almeida et al., 2004) of Minas Gerais and São 
Table 1.-List of the Aeolosaurus records in southern South America

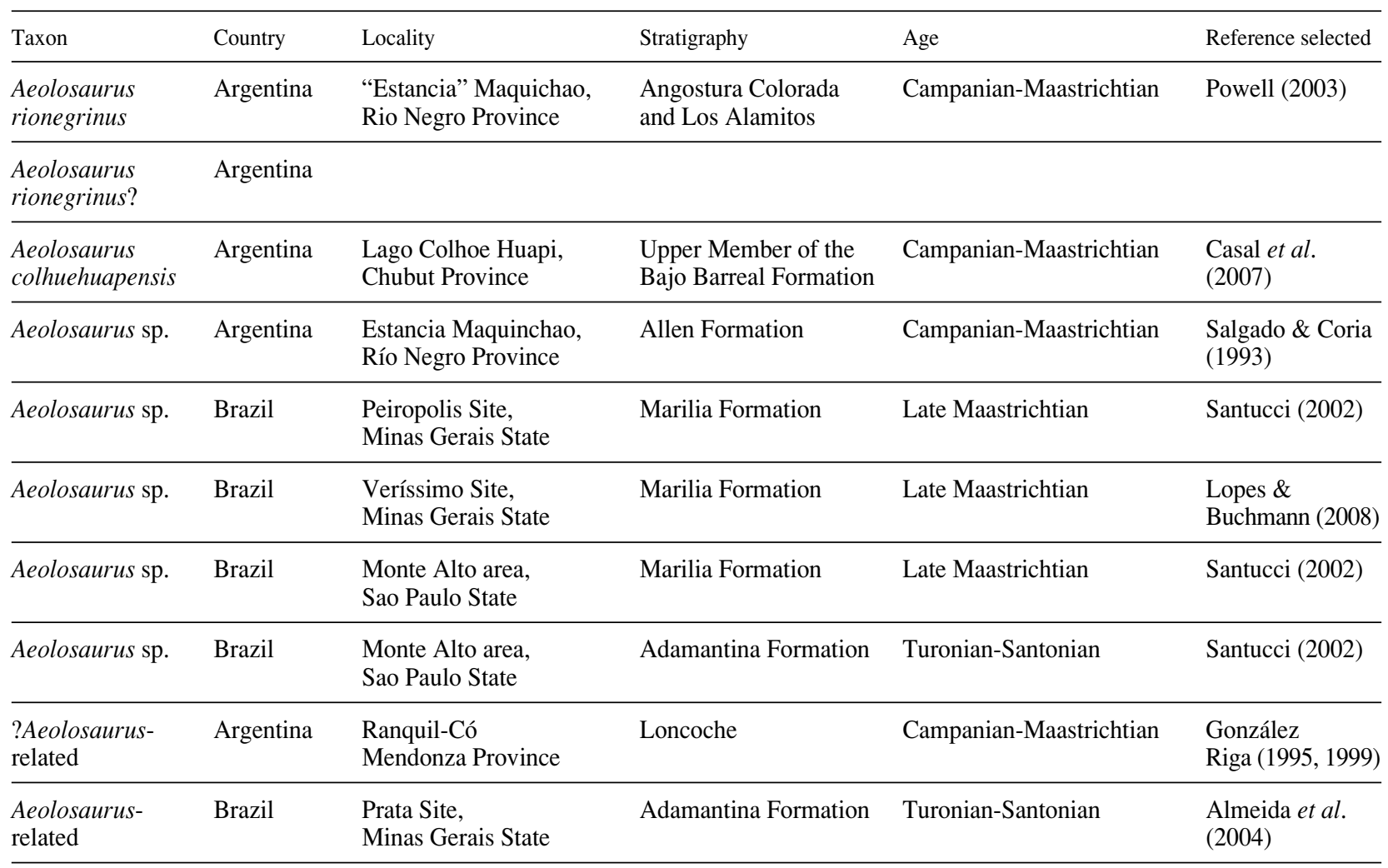

Paulo states, Brazil. The presence of the genus in the Allen, Angostura Colorada, Los Alamitos and Bajo Barreal formations indicates that the taxon was widespread in northern and central Patagonia by Campanian-Maastrichtian time. Fossils of Aeolosaurus are a common occurrence in rocks deposited during this latter time, in Argentina as well as in the Marília Formation of central Brazil.

The record of Aeolosaurus from southern South America is important for several reasons. The fossil assemblage (e.g., Aeolosaurus and the crocodyliform Peirosaurus) in Brazil correlates to the Neuquenian and Allenian faunal assemblages proposed by Leanza et al. (2004) and thus directly cross-correlates the record of Aeolosaurus and Peirosaurus to the standard southern South America Gondwanan chronostratigraphic time scale. These correlations reinforce earlier assessments by Huene (1931) that the Bauru Group and many Patagonian fossil vertebrate-bearing units (e.g., those of the Neuquén Group) are of Late Cretaceous age.

As documented in the present study, the titanosaurian genus Aeolosaurus was widespread during the Late Cretaceous. Although some reports of the genus in central Brazil and northern Patagonia are still preliminary (e.g., González Riga, 1999; Almeida et al., 2004), the fossil record of this titanosaur indicates the existence of Late Cretaceous faunal connections between the areas of southern South America where its fossils are reported (fig. 2, table 1). Sauropod dinosaurs were terrestrial animals (Powell, 1992) that consequently depended on land or land bridges as migration routes. At present, the fossil record of Aeolosaurus suggests that the taxon originated in central Brazil, then dispersed via south-central Brazil to northern Patagonia and finally to southern Patagonia (fig. 3). In contrast, other Turonian faunal elements discovered in northern Patagonia, which are similar to geologically younger South American faunas (e.g., the crocodyliform Peirosaurus tormini found in central Brazil and northern Patagonia), are often proposed to have migrated northward to central Brazil from Patagonia. The Late Cretaceous Argentinean and Brazilian record of Aeolosaurus is singular because paleogeographic reconstructions locate between central-northern Argentina and Brazil dur- 


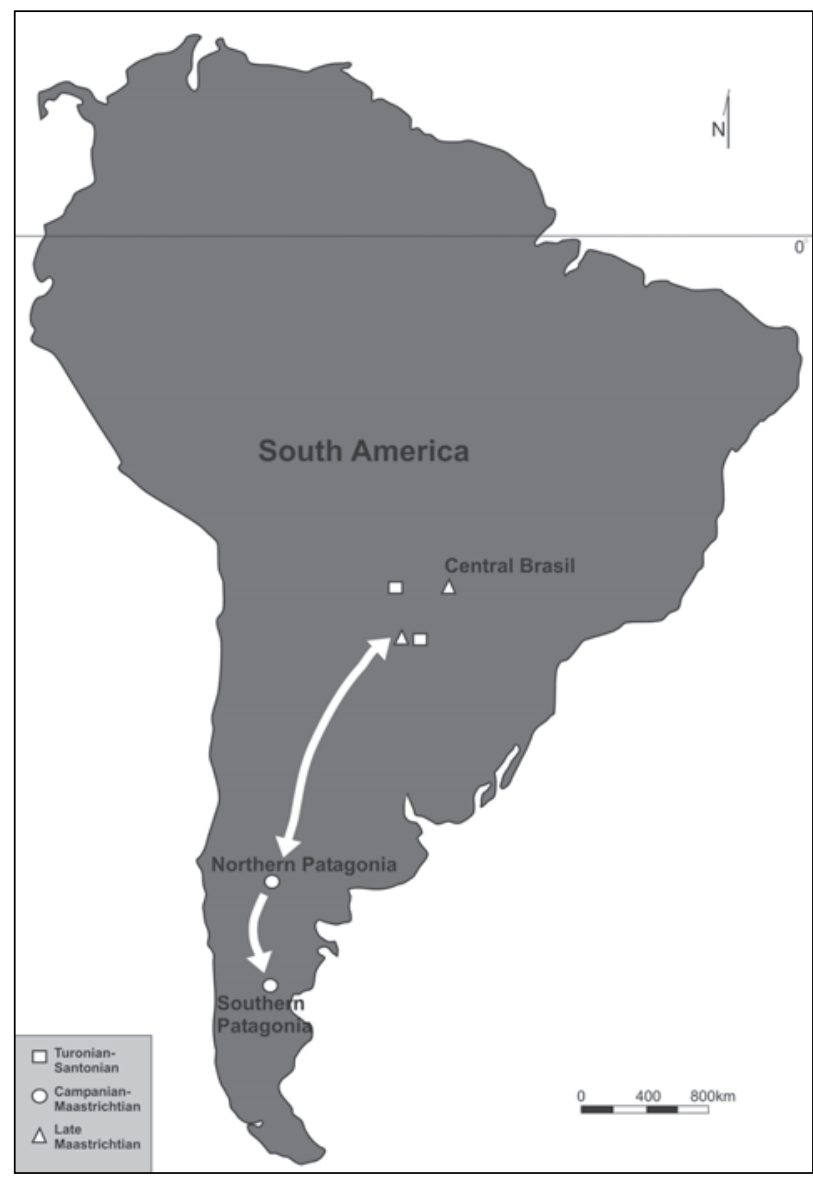

Fig. 3.-Recent word map showing Aeolosaurus Stratigraphic and geographical distribution of Aeolosaurus. Arrows indicate possible dispersal routes.

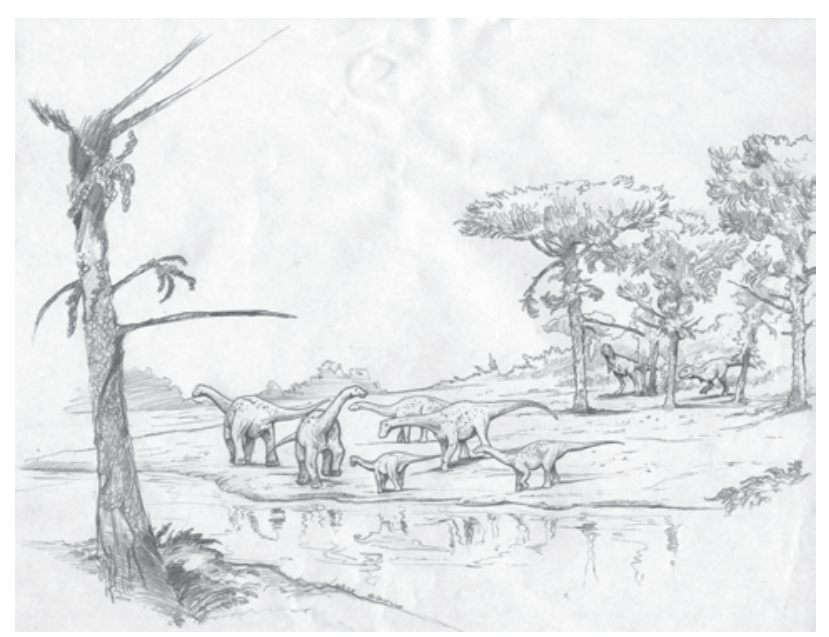

Fig. 4.-Paleoenvironmental reconstruction of some dinosaurs of the Marília Formation (Bauru Group, Brazil) showing Aeolosaurus herd (middle) and Abelisauridae theropod (right). Drawing made by J. Blanco. ing the Campanian-Maastrichtian reflect a southernwestern in the South America presence. During the Campanian-Maastrichtian, marine ingressions occurred throughout central and northern Patagonia (Pascual et al., 1996). As a result, no dinosaurian faunal interchange could have occurred between central and northern Argentina and Brazil until the Paleocene, because these marine waters would have acted as a barrier to the dispersal of dinosaur faunas from both areas. The genus Aeolosaurus persisted into the Maastrichtian in central Brazil but has not been reported in post-Campanian Argentinean beds. The stratigraphically oldest reported specimens of Aeolosaurus are from the Turonian-Santonian of central Brazil (Santucci, 2002; Almeida et al., 2004), followed by discoveries from the Campanian-Maastrichtian of Patagonia (Salgado \& Coria, 1993; González Riga, 1999; Powell, 2003) and the late Maastrichtian of Brazil (Santucci, 2002; Candeiro et al., 2008) (fig. 4). The latter represent the youngest known specimens of Aeolosaurus.

\section{Conclusions}

Upper Cretaceous Argentinean and Brazilian strata preserve an important record of aeolosaurine titanosaurs. Although the fossils of these sauropods are often fragmentary, most of them bear synapomorphies of the genus Aeolosaurus in their caudal vertebrae. The close affinity of the Aeolosaurus specimens from Brazil and Argentina expands both the stratigraphic and geographic ranges of this genus. The early Late Cretaceous (Turonian-Santonian) occurrence of Aeolosaurus extends the stratigraphic range of Aeolosaurus by approximately 28.5 million years. Geological and stratigraphic evidence suggests that central Brazil and Patagonia maintained contact through the early Late Cretaceous but became separated by a marine incursion during the Late Cretaceous (Campanian), as pointed out by Pascual et al. (1996). The occurrence of Aeolosaurus suggests that aeolosaurines were distributed at least in central Brazil and Patagonia during the Late Cretaceous, and that these two areas maintained a faunal connection at this time. This distribution is further supported by the presence of Aeolosaurus at the late Maastrichtian Peirópolis site in Minas Gerais State, where the genus apparently persisted after the marine ingression that occurred in northern Patagonia during the Campanian. Peirosaurid crocodyliforms from the Adamantina 
and Marília formations in central Brazil (i.e., Peirosaurus tormini, Uberabasuchus terrificus, Itasuchus jesuinoi) share close affinities with P. tormi$n i$ and Lomasuchus palpebrosus from coeval rocks in northern Patagonia (Gasparini et al., 1991; Bonaparte, 1996; Gasparini, 1996; Martinelli, 2003; Carvalho et al., 2004). This association further supports an early Late Cretaceous faunal connection between the two areas. The central Brazil assemblage is also broadly comparable with Late Cretaceous tetrapod assemblages from Patagonia, reaffirming the relative homogeneity of the terrestrial faunas of these two areas during this time. Additional work at other Gondwanan localities may eventually extend the ranges of these taxa throughout much of Gondwana during the Late Cretaceous.

\section{ACKNOWLEDGEMENTS}

This work was carried out in late 2004 at the Royal Tyrrell Museum of Palaeontology (RTMP) in Drumheller, Alberta, Canada. I thank F. Therrien (RTMP; Johns Hopkins University, USA) for his critical reading of an early version of the manuscript. I also thank B. González Riga (IANIGLA, Mendoza, Argentina), G. Casal (UNPSJB, Chubut, Argentina), and L. Avilla (Universidade Federal do Rio de Janeiro, Brazil) for their helpful comments. The manuscript was greatly improved by the comments of D. Gillette (Museum of Northern Arizona, Flagstaff, Arizona, USA) and T. Rich (Museum of Victoria/ Monash University, Australia). This work was made possible by technical support from P.J. Currie, D. Tanke, D. Brinkman and E. Koppelhus (RTMP). G. Casal (Argentina) made resumen translation. Matthew C. Lamanna (Carnegie Museum of Natural History, USA) made the final grammar correction and revision of the article. I am also grateful to the reviewers B. González Riga (IANIGLA, Mendoza, Argentina) and J.I. RuizOmeñaca (Museo del Jurásico de Asturias, Spain) who provide helpful critiques on the manuscript. I am especially indebted to J. Blanco (Buenos Aires, Argentina) for drawing figure 4. This study was supported by fellow from Conselho Nacional de Pesquisa/CNPq (Produtividade Pesquisa).

\section{References}

Almeida, E.B.; Avilla, L.S. \& Candeiro, C.R.A. (2004). Restos caudais associados a Titanosauridae do Cretáceo Superior da Formação Adamantina, Bacia Bauru, Município do Prata - MG. Revista Brasileira de Paleontologia, 7: 239-243. doi:10.4072/rbp.2004.2.17

Arid, F.M. (1967). A Formação Bauru na região norteocidental do estado de São Paulo. PhD Thesis, Faculdade de Filosofia, Ciências e Letras de São José do Rio Preto, 98 pp.

Barcelos, J.H. (1984). Reconstrução paleogeográfica da sedimentação do Grupo Bauru baseada na sua redefinição estratigráfica parcial em território paulista e no estudo preliminar fora do estado de São Paulo. PhD Thesis, Universidade Estadual Paulista, Rio Claro, 190 pp.

Barrio, C.A. (1990). Late Cretaceous-Early Tertiary sedimentation in a semiarid foreland basin (Neuquén Basin, western Argentina). Sedimentary Geology, 66: 255-275. doi:10.1016/0037-0738(90)90063-Y

Bertini, R.J.; Santucci, R.M.; Ribeiro, L.C.B. \& ArrudaCampos, A.C. (2000). Aeolosaurus (Sauropoda, Titanosauridae) from Upper Cretaceous of Brazil. XVI Jornadas Argentinas de Paleontología de Vertebrados, (San Luis), Actas, 1: 6.

Bonaparte, J.F. (1996). Cretaceous tetrapods of Argentina. Münchner Geowissenchaften Abhandlungen, 30: 73-130.

Bonaparte, J.F.; Franchi, M.R.; Powell, J.E. \& Sepúlveda, E.G. (1984). La Formación Los Alamitos (Campaniano-Maastrichtiano) del sudeste de Río Negro, con descripción de Kritosaurus australia n. sp. (Hadrosauridae). Significado paleogeográfico de los vertebrados. Revista de la Asociación Geológica Argentina, 39: 284-299.

Bridge, J.S.; Jafin, G.A. \& Georgieff, S.M. (2000). Geometry, lithofacies, and spatial distribution of Cretaceous fluvial sandstone bodies, San Jorge Basin, Argentina: outcrop analog for the hydrocarbon-bearing Chubut Group. Journal of Sedimentary Research, 70: 341-359. doi:10.1306/2DC40915-0E47-11D7-8643000102C1865D

Calvo, J.O.; González Riga, B.J. \& Porfiri, J.A. (2007). A new titanosaur sauropod from the Late Cretaceous of Neuquén, Patagonia, Argentina. Arquivos do Museu Nacional, 65: 485-504.

Candeiro, C.R.A. (2007). Cretaceous biota of the Triângulo Mineiro region: A review of recent finds. Estudios Geológicos, 63: 65-73. doi:10.3989/egeol.07631190

Candeiro, C.R.A. \& Martinelli, A.G. (2003). Comparison of dinosaurs and sedimentary environments between the Bauru and Neuquén-Malargüe Groups (Upper Cretaceous): A preliminary approach. Paleontologia em Destaque, 17: 48.

Candeiro, C.R.A.; Marinho, T.S. \& Oliveira, E.C. (2004). Distribuição geográfica dos dinossauros da Bacia Bauru (Cretáceo Superior). Revista Sociedade \& Natureza, 16: 33-55.

Candeiro, C.R.A.; Santos, A.R.; Rich, T.H.; Marinho, T.S. \& Oliveira, E.C. (2006a). Vertebrates fossils from the Adamantina Formation (Late Cretaceous), Prata Paleontological District, Minas Gerais State, Brazil. Geobios, 39: 319-327. doi:10.1016/j.geobios.2005.10.003

Candeiro, C.R.A.; Martinelli, A.G.; Avilla, L.S. \& Rich, T. (2006b). Tetrapods from the Upper Cretaceous (Turonian Maastrichtian) Bauru Group of Brazil: a reappraisal. Cretaceous Research, 27: 923-946. doi:10.1016/j.cretres.2006.05.002

Candeiro, C.R.A.; Santos, A.R.; Bergqvist, L.P.; Ribeiro, L.C.B. \& Apesteguía, S. 2008. Late Cretaceous fauna and flora from Peirópolis area, Minas Gerais State, Brazil. Journal of South American Earth Science, 25: 203-216. doi:10.1016/j.jsames.2007.06.005 
Carvalho, I.S.; Ribeiro, L.C.B. \& Avilla, L.S. (2004). Uberabasuchus terrificus sp. nov., a New Crocodylomorpha from the Bauru Basin (Upper Cretaceous), Brazil. Gondwana Research, 7: 975-1002. doi:10.1016/S1342-937X(05)71079-0

Casadio, S.A. (1994). Estratigrafía y Paleontología del intervalo Naastrichtiano-Daniano en el occidente de la Provincia de La Pampa, Argentina. PhD Thesis, Facultad de Ciencias Exactas, Físicas y Naturales, Universidad Nacional de Córdoba, 353 pp.

Casal, G.; Martínez, R. \& Luna, M. (2007). Aeolosaurus colhuehuapensis sp. nov (Sauropoda: Titanosauria) de la Formación Bajo Barreal, Cretácico Superior de Argentina. Revista Brasileira de Paleontologia, 10: 53-62. doi:10.4072/rbp.2007.1.05

Dias Brito, D.; Musacchio, E.A.; Castro, J.C.; Maranhão, M.S.A.; Suárez, J.M. \& Rodrigues, R. (2001). Grupo Bauru: uma unidade continental do Cretáceo do Brasil concepções baseadas em dados micropaleontológicos, isotópicos e estratigráficos. Revue Paléobiologie, 20: 245-304

Digregorio, J.H. \& Uliana, M.A. (1980). Cuenca Neuquina. Geologia regional Argentina. Academia Nacional de Ciencias, 2: 985-1032.

Fernandes, L.A. (1998). Estratigrafia e evolução geológica da parte oriental da Bacia Bauru (Ks, Brasil). $\mathrm{PhD}$ Thesis, Programa de Pós-Graduação em Geociências, Universidade de São Paulo, 216 pp.

Fernandes, L.A. \& Coimbra, A.M. (1996). A Bacia Bauru (Cretáceo Superior, Brasil). Anais da Academia Brasileira de Ciências, 68: 195-205.

Franco Rosas, A.; Salgado, L.; Rosas, C. \& Carvalho, I.S. (2004). Nuevos materiales de Titanosaurios (Sauropoda) en el Cretácico Superior de Mato Grosso, Brasil. Revista Brasileira de Paleontologia, 7: 329-336. doi:10.4072/rbp.2004.3.04

Freitas, R.O. (1955). Sedimentação, estratigrafia e tectônica da Série Bauru. Boletim da Faculdade de Filosofia e Letras da Universidade de São Paulo, 14 (194): 1-179.

Gasparini, Z.B. (1996). Biogeographic evolution of the South American crocodilians. Münchner Geowissenchaften Abhandlungen, 30: 159-184.

Gasparini, Z.B.; Chiappe, L.M. \& Fernández, M. (1991). A new Senonian peirosaurid (Crocodilomorpha) from Argentina and a synopsis of the South American Cretaceous crocodilian. Journal of Vertebrate Paleontology, 11: 316-333. doi:10.1080/02724634.1991.10011401

Gonzaga de Campos, L.F. (1905). Reconhecimento da zona compreendida entre Bauru e Itapura. São Paulo. In: Relatório Estrada de Ferro Noroeste do Brasil, São Paulo, Tipografia Ideal, 1-40.

González Riga, B.J. (1995). Estratigrafía y Paleontología de vertebrados del Cretácico Superior de Ranquil-Có, sur de la provincia de Mendoza, R. Argentina. PhD Thesis, Facultad de Ciencias Exactas, Físicas y Naturales, Universidad Nacional de Córdoba, Argentina, 133 pp.

González Riga, B.J. \& Parras, A.M. (1998). Paleoambiente y Paleontología de la Formación Loncoche (Cretácico Superior) en Ranquil-Có, sur de la provincia de Mendoza, República Argentina. VII Congreso
Argentino de Paleontología y Bioestratigrafía (Bahía Blanca), Actas, 81.

González Riga, B.J. (1999). Hallazgo de vertebrados fósiles en la Formación Loncoche, Cretácico Superior de la Provincia de Mendoza, Argentina. Ameghiniana, 36: 401-410.

González Riga, B.J. \& Calvo, J.O. (2009). A new widegauge Sauropod track site from the Late Cretaceous of Mendoza, Neuquén Basin, Argentina. Palaeontology, 52: 631-640. doi:10.1111/j.1475-4983.2009.00869.x

González Riga, B.J.; Previtera, E. \& Pirrone, C.A. (2009). Malarguesaurus florenciae gen. et sp. nov., a new titanosauriform (Dinosauria, Sauropoda) from the Upper Cretaceous of Mendoza, Argentina. Cretaceous Research, 30: 135-148. doi:10.1016/j.cretres.2008.06.006

González Riga, B.G.; Previtera, E. \& Pirrone, C.A. (2009). Malarguesaurus florenciae gen. et sp. nov., a new titanosauriform (Dinosauria, Sauropoda) from the Upper Cretaceous of Mendoza, Argentina. Cretaceous Research, 30: 135-148.

doi:10.1016/j.cretres.2008.06.006

Huene, F. von. (1927). Contribución a la paleogeografía de Sud-América - II. Las relaciones paleogeográficas de Sud-América durante el Cretáceo Superior. Academia Nacional de Ciencias de Córdoba, 30: 256-294.

Huene, F. von. (1931). Verschiedene Mesozoiche Wirbeltierreste aus Südamarika. Neus Jahrbuch fur Mineralogie, Geologie und Paläeontologie, 66: 181-198.

Huene, F. von. (1939). Carta de F. von Huene ao Dr. Euzébio de Oliveira. Mineração e Metalurgia, 4 (22): 1-190.

Kellner, A.W.A. \& Azevedo, S.A.K. (1999). A new sauropod dinosaur (Titanosauria) from the Late Cretaceous of Brazil. National Science Museum Monographs, 15: 111-142.

Lamanna, M.C.; Martínez, R.D. \& Smith, J. (2002). A definitive abelisaurid theropod dinosaur from the early Late Cretaceous of Patagonia. Journal of Vertebrate Paleontology, 22: 58-69. doi:10.1671/02724634(2002)022[0058:ADATDF]2.0.CO;2

Leanza, H.A. (1999). The Jurassic and Cretaceous terrestrial beds from southern Neuquén Basin, Argentina. Field Guide. Instituto Superior de Correlación Geológica, INSUGEO, Serie Miscelánea 4, 1-10.

Leanza, H.A. \& Hugo, C.A. (2001). Cretaceous red beds from southern Neuquén Basin (Argentina: age, distribution and stratigraphic discontinuities. VII International Symposium on Mesozoic Terrestrial Ecosystems, Buenos Aires, Asociación Paleontológica Argentina, Publicación Especial, 7: 111-122.

Leanza, H.A.; Apesteguía, S.; Novas, F. \& de la Fuente, M. (2004). Cretaceous terrestrial beds from the Neuquén Basin (Argentina) and their tetrapod assemblages. Cretaceous Research, 25: 61-87.

doi:10.1016/j.cretres.2003.10.005

Legarreta, L.; Kokogian D.A. \& Boggetti, D.A. (1989). Depositional sequences of de Malargüe Group (Upper Cretaceous-Lower Tertiary), Neuquén Basin, Argentina. Cretaceous Research, 10: 337-356. doi:10.1016/0195-6671(89)90009-8 
Lopes, R.P. \& Buchmann, F.S.C. (2008). Fossil of titanosaurs (Dinosauria, Sauropoda) from a new outcrop in Triângulo Mineiro, southeastern Brazil. Revista Brasileira de Paleontologia, 11: 51-58. doi:10.4072/rbp.2008.1.07

Martinelli, A.G. (2003). New cranial remains of the bizarre notosuchid Comahuesuchus brachybuccalis (Archosauria, Crocodyliformes) from the Late Cretaceous of Río Negro Province (Argentina). Ameghiniana, 40: 559-572.

Martínez, R. (1998). Notohypsilophodon comodorensis gen. et sp. nov. Un Hypsilophodontidae (Ornithischia, Ornithophoda) del Cretácico Superior de Chubut, Patagonia Central. Acta Geológica Leopoldensia, 21: 46-47,

Martínez, R.D.; Giménez, O.; Rodríguez, J.; Dodson, P. \& Luna, M. (2000). Dinosaurs from the Bajo Barreal Formation, central Patagonia. Journal of Vertebrate Paleontology, 20 (3, suppl.): 57A.

Martínez, R.D.; Jiménez, O.; Rodríguez, J.; Luna, M. \& Lamanna, M.C. (2004). An arituclated specimen of the basal titanosaurian (Dinosaurio: Sauropoda) Epachthosaurus sciuttoi from the eraly Late Cretaceous Bajo Barreal Formation of Chubut Province, Argentina. Journal of Vertebrate Paleontology, 24: 107-120. doi:10.1671/9.1

Mezzalira, S. (1974). Contribuição ao conhecimento da estratigrafia e paleontologia do Arenito Bauru. Boletim do Instituto de Geográfica e Geologia, 51: 1-163.

Parras, A.M.; Casadío S. \& Pires, M. (1996). Secuencias depositacionales del Grupo Malargüe y El límite Cretácico-Paleógeno, en el sur de la Provincia de Mendoza, Argentina. Asociación Paleontológica Argentina, Publicación Especial 5, Paleógeno de América del Sur y Península Antártica, 61-69.

Pascual, R.; Ortiz Jaureguizar, E \& Prado, J.L. (1996). Land Mammals: Paradigm for Cenozoic South American Geobiotic Evolution. Muncher Geowissenschaftliche Abhandlungen, 30: 265-319.

Powell, J.E. (1987). The Late Cretaceous fauna of Los Alamitos, Patagonia, Argentina. Part VI. The titanosaurids. Revista del Museo Argentino de Ciencias Naturales "Bernardino Rivadavia”, 3: 147-153.

Powell, J.E. (1992). Osteología de Saltasaurus loricatus (Sauropoda-Titanosauridae) del Cretácico Superior del Noroeste argentino. In: Los Dinosaurios y Su Entorno Biótico (Sanz, J.L \& Buscalioni, A.D., eds.). Instituto Juan de Valdés, Excmo. Ayuntamiento de Cuenca, 166-230.

Powell, J.E. (2003). Revision of South American titanosaurid dinosaurs: paleobiological, paleobiogepgraphical and phylogenetic aspects. Records of the Queen Victoria, 111: 1173.

Previteria, E. \& González Riga, B.J. (2008). Vertebrados cretácicos de la Formación Loncoche em Calmu-Co, Mendoza, Argentina. Ameghiniana, 45: 349-359.

Remane, J. (2000). Explanatory note to the international stratigraphic chart. Publication courtesy of the Division of Earth Sciences, UNESCO. XXXI International Geological Congress, (Rio de Janeiro), Abstracts, CD.
Salgado, L. \& Coria, R.A. (1993). El gênero Aeolosaurus (Sauropoda, Titanosauridae) en la Formación Allen (Campaniano-Maastrichtiano) de la Provincia de Río Negro, Argentina. Ameghiniana, 30: 119-128.

Salgado, L. \& García, R. (2002). Variación morfológica en la secuencia de vertebras caudales de algunos sauropods titanosaurios. Revista Española de Paleontología, 17: 211-216.

Salgado, L.; Coria, R.A. \& Calvo, J.O. (1997). Evolution of Titanosaurid Sauropods. I: Phylogenetic analysis based on the postcranial evidence. Ameghiniana, 34: 3-32.

Santucci, R.M. (2002). Revisão dos titanosaurideos do Cretáceo Superior do Brasil. PhD Thesis, Universidade Estadual Paulista, Rio Claro, 179 pp.

Santucci, R. \& Arruda-Campos, A. (2009). The phylogenetic relationships of a new aelosaurini titanosaur from the Adamantina Formation, Bauru Group, Upper Cretaceous of Brazil. Journal of Vertebrate Paleontology, 29 (supplement to number 3): 176A.

Sciutto, J.C. \& Martínez, R.D. (1994). Un nuevo yacimiento fosilífero de la Formación Bajo Barreal (Cretácico tardío) y su fauna de sauropodos. Naturalia Patagonica, Ciencias de la Tierra, 2: 27-47.

Soares, P.C.; Landim, P.M.B.; Fúlfaro, V.J. \& Neto, A.F.S (1980). Ensaio de caracterização estratigráfica do Cretáceo no Estado de São Paulo: Grupo Bauru. Revista Brasileira de Geociências, 10: 177-185.

Suguio, K. (1980). Fatores Paleoambientais e Paleoclimáticos e Subdivisão Estratigráfica do Grupo Bauru: Mesa Redonda sobre a Formação Bauru no estado de São Paulo e Regiões Adjacentes. Sociedade Brasileira de Geologia, Núcleo São Paulo, 5: 15-26.

Upchurch, P.; Barret, P.M. \& Dodson, P. (2004). Sauropoda. In: The Dinosauria $2^{\text {nd }}$ ed (Weishampel, D.B.; Dodson, P. \& Osmolska, H., eds.). University of California Press, 259-322.

Washburne, C.W. (1930). Petroleum geology of the State of São Paulo, Brazil. Boletim Comissão Geológica e Geográfica de São Paulo, 22: 1-282.

Wichmann, R. (1927). Sobre la facies lacustre Senomaniana de los estratos con dinosaurios y su fauna. Boletín de la Academia Nacional de Ciencias, 30: 383-405.

Wilson, J.A. (2002). Sauropod dinosaur phylogeny: critique and cladistic analysis. Zoological Journal of the Linnaean Society, 136: 217-276. doi:10.1046/j.10963642.2002.00029.x

Wilson, J. \& Sereno, P.C. (1998). Early evolution and higher-level phylogeny of sauropod dinosaurs. Society of Vertebrate Paleontology Memoir, 5 (Supplement to Journal of Vertebrate Paleontology, 18): 1-68.

Wilson, J.A. \& Upchurch, P. (2003). A revision of Titanosaurus Ludekker (Dinosauria - Sauropoda), the first dinosaur genus with a "Gondwanan" distribution. Journal of Systematic Paleontology, 1: 125-160. doi:10.1017/S1477201903001044

Recibido el 26 de agosto de 2009 Aceptado el 9 de junio de 2010 Publicado online el 3 de diciembre de 2010 